\title{
The Role of CT Scan in Recognizing Blunt Diaphragmatic Rupture
}

\author{
Edward Passos, Bartolomeu Nascimento, Fernando Spencer Netto, Homer Tien, Sandro Rizoli
}

\begin{abstract}
Background: Blunt traumatic diaphragmatic rupture (BTDR) occurs when significant deceleration mechanism and energy are applied to the torso, and it is associated with significant injuries and high morbidity and mortality. Although it has limitations, CT scan is the diagnostic of choice for BTDR. This study is a retrospective analyse of our experience in diagnosing BTDR using the 64-slice CT scanner. Sensitivity and specificity of this exam were assessed.
\end{abstract}

Methods: We reviewed reports from 2006 to 2009 of all CT scans of the abdomen that were done in the first 24 hours of hospitalization of blunt trauma patients. We compared CT findings to surgery reports.

Results: Our cohort consisted of 2670 patients; $69 \%$ were male. We found 28 cases of BTDR, most of them on the patient's left side $(54 \%)$. Eleven percent of cases were bilateral. BTDR was often caused by motor vehicle collisions. We found sensitivity of $86 \%$, specificity of $99 \%$.

Conclusion: CT scan is reliable tool in blunt trauma patients. As new technologies arise, its sensibility and specificity also increases.

Keywords: Diaphragmatic rupture, Blunt trauma, CT scan.

How to cite this article: Passos E, Nascimento B, Netto FS, Tien H, Rizoli S. The Role of CT Scan in Recognizing Blunt Diaphragmatic Rupture. Panam J Trauma Critical Care Emerg Surg 2012;1(1):24-26.

Source of support: Nil

Conflict of interest: None declared

\section{RESUMEN}

Introducción: La ruptura diafragmática traumática embotada (RDTE) ocurre cuando la energía significativa de la desaceleración se aplica al torso, y él se asocia a lesiones significativas, y altas morbilidad y mortalidad. Aunque tiene limitaciones, la tomografía computarizada (TC) es el diagnóstico de la opción para RDTE. Este estudio es un análisis retrospectivo analiza de nuestra experiencia en diagnosticar RDTE usando escanografía multicorte. La sensibilidad y la especificidad de este examen fueron determinadas.

Métodos: Repasamos informes a partir de 2006 a 2009 de todas las e TC del abdomen que fueron hechas en el primer $24 \mathrm{~h}$ de la hospitalización de los pacientes con trauma embotado. Comparamos resultados de TC a los informes de la cirugía.

Resultados: Nuestra cohorte consistió en 2670 pacientes; los $69 \%$ eran masculinos. Encontramos 28 casos de RDTE, la mayor parte de él en el lado izquierdo del paciente (el 54\%). los $11 \%$ de casos eran bilaterales. RDTE fue causado a menudo por colisiones del vehículo de motor. Encontramos la sensibilidad de el $86 \%$, especificidad de el $99 \%$.

Conclusiones: La TC es herramienta confiable en pacientes del trauma embotado. Como se presentan las nuevas tecnologías, sus aumentos de la sensibilidad y de la especificidad también.
Palabras clave: Ruptura diafragmática, traumática embotada /contusa, tomografía computarizada (TC).

\section{BACKGROUND}

Blunt traumatic diaphragmatic rupture (BTDR) may occur when significant energy is applied to the torso. The occurrence of BTDR usually indicates the existence of associated injuries, ${ }^{1,2}$ which bear significant morbidity and mortality. ${ }^{3}$ Several mechanisms, such as compression of intra thoracic structures; impairment of ventilation; strangulation or rupture of herniated organs with spillage of visceral content, and subsequent infection; and chronic herniation may account for the high mortality associated with BTDR. ${ }^{3-6}$ Despite the clinical significance of BTDR and the recent advances in imaging, its diagnosis remains challenging, and this may compromise the timely management of this injury. ${ }^{7}$ Despite some limitations, computed tomography (CT) scan continues to be widely used as the preferred imaging method to identify BTDR for decades. ${ }^{8,9}$ Recently, the newer generation 64-slice CT scan was introduced into clinical practice with an implied expectation of being able to reduce the number of misdiagnosis including of BTDR. ${ }^{10,11}$ We decided to review our experience with this equipment and test its ability to diagnose BTDR in our center.

\section{OBJECTIVE}

Review the experience of Sunnybrook Health Sciences Centre (SHSC) in the diagnosis of BTDR based on the 64 slice CT scan of the abdomen.

\section{METHODS}

\section{Study Description}

After Research Ethical Board approval, we performed a retrospective review from January 2006 to December 2009 of patients sustaining blunt trauma of torso who underwent CT scan of abdomen in the first 24 hours. Surgery was considered the gold standard (Thoracotomy or VATS; exploratory laparotomy or laparoscopy) for the confirmation of BTDR.

\section{Setting}

Sunnybrook Health Sciences Centre (SHSC) is a large Academic Trauma Centre in Canada, where approximately 1,100 severely traumatized patients are admitted yearly, with a mean injury severity score (ISS) of 30 . We have 
continuously available a full time trauma team and fully equipped imaging center, with 64 slices CAT scan.

\section{Variables Collected}

Clinical and radiology data were retrieved from the hospital chart and electronic patient records. Our trauma registry database was used to obtain data on injury severity scores. Demographics and physiologic data included: Age, gender, glasgow coma scale (GCS), injury severity score (ISS), length of stay (LOS), mechanism and type of injury, associated injuries.

\section{Outcomes}

The main outcome of the study was the identification of BTDR in CT scan using surgery as the gold standard. Since, we used surgery as gold standard for BTDR, we calculated sentivity and specificity for those that underwent surgical procedure $(\mathrm{n}=157)$.

The secondary outcomes were associated injuries, deaths, and length of stay.

\section{RESULTS}

During the 4-year study period, we had 2670 trauma patients who underwent $\mathrm{CT}$ scan of abdomen in the first 24 hours. From this population, 25 had positives CT scans for BTDR. Overall, 157 patients underwent surgery and BTDR was found on 28 patients (Table 1). One false-positive was found on the right side. Four false-negatives were found at right side. The right side component on bilateral injuries was missed in three cases. We found sensitivity of $86 \%$, specificity of $99 \%$.

The most common mechanism of injury was motor vehicle collision (MVC), found in $89 \%$ of cases. All cases of BTDR involved a vehicle, being MVC, recreational MVC, or pedestrian struck by a vehicle (Table 2).

The presence of free fluid was the most common finding $(79 \%)$ in BTDR, regardless the side of injury. Liver injuries were found most commonly in right BTDR, but it was also common in left ruptures. The presence of pelvic and rib fracture was usual, and can be related to the high level of energy involved in those traumas (Table 3). Other findings included lesions to spleen, mesentery, bowel, pancreas and kidney.

The length of stay for survivors was 9 days (range 3-18). The in-hospital mortality rate was $14 \%$. In fatal cases, the left side was involved in $13 \%$, whereas the right side was not involved in none of the cases. Bilateral cases were found in $67 \%$ of nonsurvivors, expressing the severity of the case and associated injuries (Table 4).

\section{CONCLUSION}

We found that CT scan is a valuable tool in trauma patients, despite not being considered the gold standard for the diagnosis of blunt diaphragmatic rupture. In our study it only incorrectly diagnosed five cases since, we had missed injuries or false-positives at the right side.

CT scan showed a good sensitivity and excellent specificity; although someone may argue the lack of long-term follow-up on those patients.

\begin{tabular}{|c|c|c|c|c|c|}
\hline \multirow[t]{2}{*}{ Data } & \multirow{2}{*}{$\begin{array}{l}\text { Population } \\
A b C T^{1} 24 \text { hours } \\
(n=2670)\end{array}$} & \multicolumn{4}{|c|}{ BTDR } \\
\hline & & Total $(n=28)$ & Left $D I(n=15)$ & Right $D I(n=10)$ & Bilateral DI $(n=3)$ \\
\hline Percentage & $100 \%$ & $1 \%$ & $54 \%$ & $36 \%$ & $11 \%$ \\
\hline Male (\%) & $69 \%$ & $54 \%$ & $60 \%$ & $40 \%$ & $67 \%$ \\
\hline Age & $45 \pm 20$ & $42 \pm 17$ & $40 \pm 15$ & $42 \pm 17$ & $53 \pm 28$ \\
\hline Direct & 1489 & $13(46 \%)$ & $8(53 \%)$ & $3(30 \%)$ & $2(67 \%)$ \\
\hline Time to arrival (m) & $90(50-300)$ & $130(59-223)$ & $120(55-232)$ & 145 (83-206) & $70(70-177)$ \\
\hline
\end{tabular}

${ }^{1} \mathrm{Ab}$ CT: Abdominal CT scan

Table 2: Mechanism of injury

\begin{tabular}{|c|c|c|c|c|c|}
\hline \multirow[t]{2}{*}{ Data } & \multirow{2}{*}{$\begin{array}{l}\text { Population } \\
\text { Ab CT } 24 \text { hours } \\
(n=2670)\end{array}$} & \multicolumn{4}{|c|}{$B T D R$} \\
\hline & & Total $(n=28)$ & Left DI $(n=15)$ & Right DI $(n=10)$ & Bilateral DI $(n=3)$ \\
\hline $\mathrm{MVC}^{1}$ & 1316 & 25 (89\%) & $15(100 \%)$ & $7(70 \%)$ & $3(100 \%)$ \\
\hline Pedestrian & 411 & $1(4 \%)$ & 0 & $1(10 \%)$ & 0 \\
\hline Recreational MVC & 97 & $2(7 \%)$ & 0 & $2(20 \%)$ & 0 \\
\hline Other & 846 & 0 & 0 & 0 & 0 \\
\hline
\end{tabular}

${ }^{1}$ MVC: Motor vehicle collision 


\begin{tabular}{lllll}
\hline & & Table 3: Associated findings in BTDR & \\
\hline Finding/injury & Total $(n=28)$ & Left DI $(n=15)$ & Right DI $(n=10)$ & Bilateral DI $(n=3)$ \\
\hline Free fluid & $22(79 \%)$ & $12(80 \%)$ & $8(80 \%)$ & $2(67 \%)$ \\
Liver & $16(57 \%)$ & $8(53 \%)$ & $7(70 \%)$ & $1(33 \%)$ \\
Pelvic fracture & $15(54 \%)$ & $9(60 \%)$ & $4(40 \%)$ & $2(67 \%)$ \\
Rib fracture & $14(50 \%)$ & $8(53 \%)$ & $5(50 \%)$ & $1(33 \%)$
\end{tabular}

\begin{tabular}{|c|c|c|c|c|c|}
\hline \multicolumn{6}{|c|}{ Table 4: Other Secondary Outcomes } \\
\hline \multirow[t]{2}{*}{ Data } & \multirow{2}{*}{$\begin{array}{l}\text { Population } \\
\text { Ab CT } 24 \text { hours } \\
(n=2670)\end{array}$} & \multicolumn{4}{|c|}{$B T D R$} \\
\hline & & Total $(n=28)$ & Left $D I(n=15)$ & Right DI $(n=10)$ & Bilateral DI $(n=3)$ \\
\hline Deaths & 236 & $4(14 \%)$ & $2(13 \%)$ & $0(0 \%)$ & $2(67 \%)$ \\
\hline ISS $^{1}$ & $23(14-34)$ & $39(29-43)$ & $33(27-41)$ & $42(36-47)$ & $38(36-47)$ \\
\hline $\operatorname{LOS}^{2}$ & $9(3-18)$ & $16(10-28)$ & $15(9-17)$ & $27(21-44)$ & $5(4-18)$ \\
\hline
\end{tabular}

${ }^{1}$ ISS: Injury severity score; ${ }^{2}$ LOS: Length of stay

\section{REFERENCES}

1. Ramos CT, Koplewitz BZ, Babyn PS, Manson PS, Ein SH. What have we learned about traumatic diaphragmatic hernias in children? Journal of Pediatric Surgery 2000 Apr;35(4):601-04.

2. Nursal TZ, Ugurlu M, Kologlu M, Hamaloglu E. Traumatic diaphragmatic hernias: A report of 26 cases. Hernia 2001 Mar; 5(1):25-29.

3. Tiberio GA, Portolani N, Coniglio A, Baiocchi GL, Vettoretto N, Giulini SM. Traumatic lesions of the diaphragm. Our experience in 33 cases and review of the literature. Acta Chir Belg 2005 Feb;105(1):82-88.

4. Abboud B, Tabet G, Bou Jaoude J, Sleilaty G. Gastric incarceration and perforation following posttraumatic diaphragmatic hernia: Case report and review of the literature. J Med Liban 2007 Apr-Jun;55(2):104-07.

5. Mortelmans, Luc JM. Jutten, Guido CY. Coene Luc. Acute posttraumatic tension gastrothorax, a tension pneumothorax-like injury. European Journal of Emergency Medicine 2003 Dec; 10(4):344-46.

6. Ueno Katsuhito, Murota Y, Takeda M, Katayama A, Tanaka K. Delayed traumatic diaphragmatic hernia with strangulated stomach; Report of a case. Kyobu Geka - Japanese Journal of Thoracic Surgery 2008 May;61(5):423-26.

7. Alimoglu O, Eryilmaz R, Sahin M, Ozsoy MS. Delayed traumatic diaphragmatic hernias presenting with strangulation. Hernia 2004 Dec; 8(4):393-96.

8. Scaglione M, Pinto F, Grassi R, Romano S, Giovine S, Sacco M, Forner AL, Romano L. Diagnostic sensitivity of computerized tomography in closed trauma of the diaphragm. Retrospective study of 35 consecutive cases. Radiol Med 2000 Jan-Feb;99(1-2):46-50.

9. Duverger V, Saliou C, Lê P, Chatel D, Johanet H, Acar C, Gigou F, Laurian C. Blunt force rupture of the thoracic aorta and diaphragm: An unusual association. Ann Chir 2001 May;126(4):339-45.
10. Barbiera F, Nicastro N, Finazzo M, Lo Casto A, Runza G, Bartolotta TV, Midiri M. The role of MRI in traumatic rupture of the diaphragm. Our experience in three cases and review of the literature. Radiol Med 2003 Mar;105(3):188-94.

11. Killeen KL, Mirvis SE, Shanmuganathan K. Helical CT of diaphragmatic rupture caused by blunt trauma. AJR Am J Roentgenol 1999 Dec;173(6):1611-16.

\section{ABOUT THE AUTHORS}

\section{Edward Passos}

Department of General Surgery, Sunnybrook Health Sciences Centre University of Toronto, Toronto, ON, Canada

\section{Bartolomeu Nascimento}

Department of Critical Care Medicine, Sunnybrook Health Sciences Centre, University of Toronto, Toronto, ON, Canada

\section{Fernando Spencer Netto}

Department of General Surgery, Sunnybrook Health Sciences Centre University of Toronto, Toronto, ON, Canada

\section{Homer Tien}

Department of General Surgery, Canadian Forces Health Services Department of National Defense, Canada

\section{Sandro Rizoli}

Department of General Surgery and Critical Care Medicine Sunnybrook Health Sciences Centre, University of Toronto, Toronto ON, Canada 